\title{
ACQUAINTING INVENTIVE MEDIA: E-INK TO TRIGGER STUDENTS' CREATIVITY IN WRITING RECOUNT TEXTS
}

\author{
Luky Tiasari \\ University of Sarjanawiyata Tamansiswa \\ slukytia_ai@yahoo.co.id
}

\begin{abstract}
One of the foreign languages used in Indonesian schools is English. Before teaching it to the students, teachers should know the characteristics of the students and how to teach them both in spoken and written forms appropriately. It is provided by students to minimize the breakdown of communication in their daily life. In this paper, I would like to propose inventive media: E-INK (Enjoy writing texts using colourful ink) for writing recount texts to the eighth graders of junior high school consisting of three ways: Idyll, Nest and Key. Plomp's model of Research and Development (1997) was used to develop this product by conducting a preliminary study, development and expert judgements in the evaluation stage. Three results of this research revealed that a) All of the E-INKs' tasks and activities were suitable for basic competence and the students' need. b) The E-INK afforded songs to develop the students' ideas in creating recount texts. c) The writing template offered save and edit models pertaining to the students' interest.
\end{abstract}

Keywords: E-INK: Idyll, Nest and Key, Writing: recount texts

\section{INTRODUCTION}

Every country in the world has unique cultures, and one of the elements that influences the cultures is language. A language also has features that are related to cultures. It means that, if an addressee cannot understand the speaker's message in the social interaction, the communication will not run smoothly. It happens because of speakers' different age, education and social backgrounds. Therefore, before teaching foreign languages to students, teachers should understand how to use a language and the characteristics of students in order to minimize the communication breakdown.

One of the foreign languages used in Indonesian schools is English. The students begin to learn it from the elementary school. To support this demand, creative English teachers have the big responsible to teach students not only the language grammar, but also the language learning atmosphere. The description of words can change language forms into sentences in that language. Harmer (2003:11) emphasizes the important role of creative teacher, so that the students can also learn a language effectively when they are using it both in spoken and written forms.

Every student has different abilities to achieve English competence. Several problems emerge in teaching writing processes such as students sometimes got difficulties to identify and write kinds of texts, developed ideas for their writing and chose proper transition signals. English

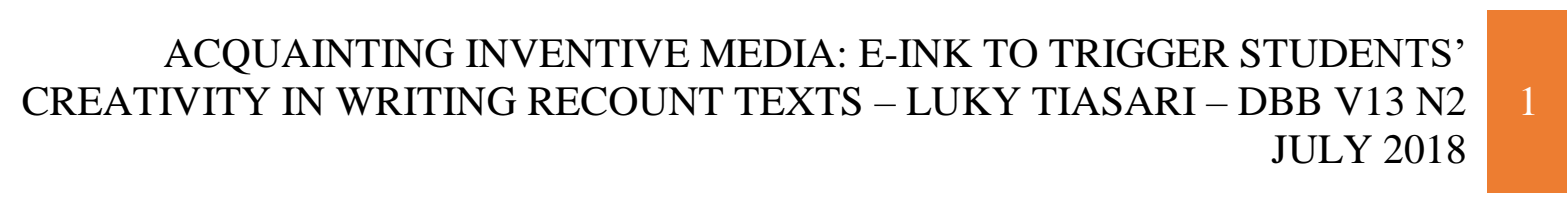


teachers have endeavored to use kinds of approaches, methods, techniques, procedures and teaching media to transfer the writing materials to students, but the results have not been maximally achieved. Therefore, the researcher developed an inventive media: E-INK to trigger students' creativity in writing recount texts to the eighth graders of junior high school consisting of three ways: Idyll, Nest and Key.

\section{The Development of Writing Media}

In developing the writing media, teachers require writing materials. When the teachers start to prepare materials before teaching, they have to think first, their materials have referred to the students' need, whether the students engage or not. It is very crucial because the function of using materials is to help students to acquire a language in the classroom such as by giving them exercises, presentations, projects, tasks and activities. The teachers can develop writing skills in the form of supplementary activities: materials intended to provide additional language experience or instruction, textbooks, or digital materials: it uses technology like computer or multimedia (Tomlinson, B., Hitomi, M. 2018).

Teaching media for English teachers are used to deliver the English materials easily. Media can help the teacher to achieve the learning objectives by transferring the materials to the students attractively. Songs, flashcards, stories, games, PowerPoint, puppets or puzzle are the examples. It can be traditional or modern media. The function of using technology is not only limited to the classroom walls, but also an equal opportunity for everyone to learn and to limit students' ability to compete in the world (https://us.corwin.com/sites/default/files/upmbinaries/6635_tileston_9_ch_1.pdf). Before using the media, English teachers should acknowledge kinds of media that the students like in order to reach English competence well.

The researcher selected song and story as media to trigger students' creativity in writing recount texts based on the following reasons:

Firstly, song is a lyric that has sounds that can be used as media to make the students happy, relaxed and fun in learning English. Most of the teachers use songs to teach English. If there is a song that contains English materials in its lyrics, it will be good in learning English. Conversely, if every song can be learned through teaching writing, it will effectively be done. Because of many advantages from the songs, the researcher has created several inventive songs as her products of research.

Secondly, story is a description of a sequence of events, news or topics. People like to read a story because it can amuse or entertain them. It can be said that reading a story is really enjoyable. By reading an activity in the E-INK: nest ways, the students can improve their vocabulary, identify kinds of texts, and get a lot of ideas, then they can begin to create a recount texts based on their experiences using the provided template.

\section{Creativity in Writing recount texts}

In teaching English, the teachers have the opportunity to use kinds of approaches or methods. Nunan, D. (1996:14) points out that changing views on the nature of language and learning between traditionalism and Communicative Language Teaching (CLT) can be seen from theory of language, theory of learning, objectives, syllabus, activities, role of learner, role of teacher and role of materials. The goal of CLT is communicative competence that is different from previous approaches. It includes the following aspects of language knowledge that relates

\footnotetext{
ACQUAINTING INVENTIVE MEDIA: E-INK TO TRIGGER STUDENTS' CREATIVITY IN WRITING RECOUNT TEXTS - LUKY TIASARI - DBB V13 N2 
to genre based approach such as how to produce and understand different types of texts (Richards: 2006: 3). Descriptive, narrative, recount, procedure and report texts are the examples of texts which have to be mastered by junior high school students.

In writing a recount text, students need to consider kinds of experiences (unforgettable experiences) that they would be chosen. The purpose of writing a recount text is to retell someone's past experience in chronological orders using past tense and linking words to do with time by ordering the story from orientation (such as: when, who, where), series of events (events that happened orderly) and reorientation (what happened in the end). If the students want to create a recount text, they should know the characteristics namely generic structure and language focus (Derewianka, B:1990).

\section{INVENTIVE MEDIA: E-INK}

To assist the teachers in delivering materials to the students effectively, the researcher has developed an innovative media called E-INK (Enjoy writing texts using colourful ink) as an inventive media that was developed for writing recount texts to the eighth graders of junior high school consisting of three ways: Idyll, Nest and Key. Basically, E-INK has three main ways. First, Idyll is a part for the students to search for ideas by listening and doing tasks and activities based on the songs given. Second, Nest consists of some stories to help the students understand how to create recount texts. Finally, Key is a creative design to trigger students to make recount texts in accordance with the template provided.

\section{RESEARCH METHOD}

Plomp's model of Research and Development (1997) was used to develop the inventive media consisting of 5 (five) stages. The researcher modified them and did these stages as follows: In the preliminary study, the researcher conducted observation and interview to create guidelines on developing inventive media for the eighth graders students of junior high school in SMP Bina Jaya. They had some problems in learning both in students' writing competence and less intriguing of media for teaching writing. Next, the researcher developed the first draft of the media called E-INK. In the internal evaluation stage, two expert judgements and two teachers met to validate E-INK product through Forum Group Discussion (FGD) by filling out the instruments comprising of content, writing skills that develop tasks and activities and graphics. Then, the researcher revised the prototype of the inventive media: E-INK.

\section{RESULTS AND DISCUSSION}

In the preliminary study, after the researcher observed and interviewed the eighth graders students of junior high school, she made a need analysis to know the target needs and learning needs. The results are stated as follows: 1) From the students' necessities, lacks and wants side: The students' objective of learning English writing was to write recount texts, but they often got confused to differentiate between recount and narrative texts and to catch the meaning of songs so they wanted their teacher to pick out the materials, tasks and activities that could improve their knowledge in writing by using an inventive media. 2) Next, from learning needs side: the students wanted to create recount texts by searching for ideas in the inventive songs, identifying the engrossing stories and writing using the provided template in tasks and activities both in individual and in group. The students also wanted the teachers to give detailed explanations

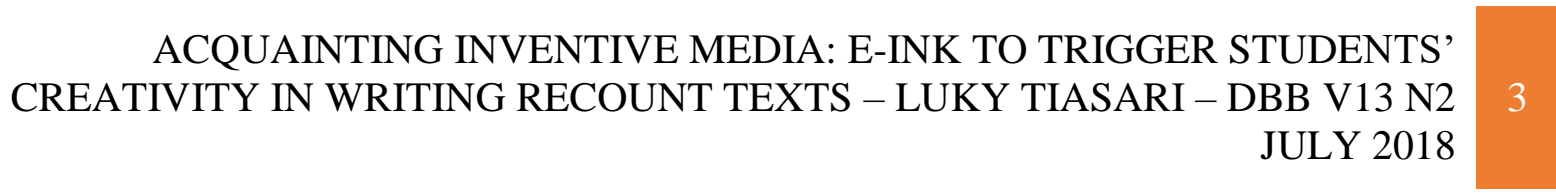


when the students got difficulties with the materials, helped them in using digital media and gave feedback on their writing.

Next, the researcher continued to develop the first draft of inventive media called E-INK. It is an inventive media application that can be used in the laptop or smart phone. It stands for Enjoy writing texts using colourful ink. It means that when the students begin to write kinds of texts, they can use colourful inks in their pen to highlight their ideas based on their creativity. She developed the writing materials through tasks and activities based on the basic competences (KD): 4.15 (Menyusun teks recount lisan dan tulis, pendek dan sederhana, tentang kegiatan, kejadian, peristiwa, dengan memperhatikan fungsi sosial, struktur teks, dan unsur kebahasaan yang benar dan sesuai konteks) and 4.19 (Menangkap makna lagu), then elaborated them using a communicative and genre based approach. Writing a recount text was selected to overcome the students' problems to write recount texts creatively. The three ways in E-INK were explained as follows:

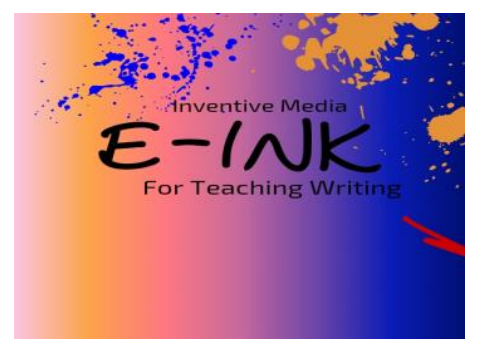

Figure 1. Inventive Media: E-INK for Teaching Writing

(a) Idyll is created by making lyrics of songs that contain several materials in certain topics in order to increase the students' vocabulary, warm up the students' mind, and encourage the students' motivation before writing recount texts. In this part, it has two songs (Cute Shopping and Spending Time) which had been designed to solve the students' problem in using modal auxiliary, past tense and vocabulary in writing recount texts. In every song, the students have chances to listen to and do some tasks related to the songs' lyrics to trigger the students' creativity by following three activities:

\section{Activity 1}

The students listen to the song carefully, and then they determine how to use modal auxiliaries (can-may-must-shall-will --- could-might-had to-should-would) from the given songs' lyrics. They do not write incorrect patterns again such as: I will to eat a plate of fried noodle. // My mother must cooking in the kitchen. // She could bought this sieve. A matching activity is also given for students to learn pronouns as subjects: I, You, We, They, He and She. They do not think if they create a sentence using modal auxiliaries. Take an example: Rondi could buy books in the bookshop. The students do not write "Rondi could buys books in the bookshop or Rondi could bought books in the bookshop". The students write "could buys" because they only remember if they see the subjects (He, She It) they have to add the letter "s" and if they see the word "could", they directly write "could bought" using the past form. In this case, the students" language is influenced by their mother tongue. The best way for students to avoid their problem is by identifying the use of modal auxiliaries through the provided game.

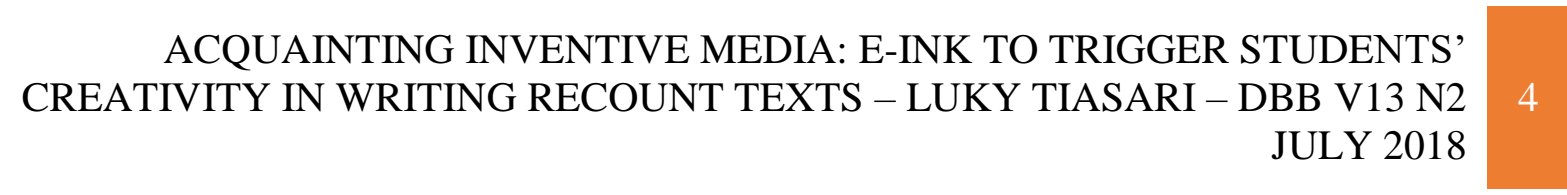




\section{Activity 2}

Besides learning modal auxiliaries, the students learn kinds of verbs that can be used in their writing style such as: go, answer, forget, bring, see, say, do, replay, need, cost, pay, buy, bargain, look for, sell, spend, occur, give, obtain, remind, etc. Fill in the blank activity serves the students to increase their vocabulary by memorizing a lot of verbs. When the students click a verb in the songs' lyrics, they would see a box that they have to fill in using the past form of that verb. At the end of this activity, the score would appear. It makes students know their English competence.

\section{Activity 3}

Through the provided songs, students can guess and explain the song's message by answering some questions and writing their opinions related to the song. This activity triggers the students to search for ideas based on the given songs.

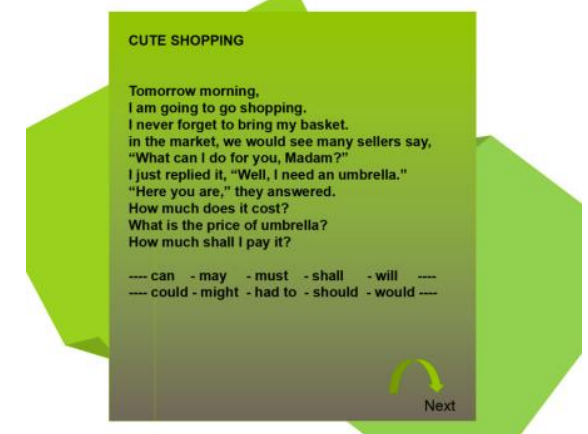

Figure 2. The Lyric of a Cute Shopping Song

(b) Nest is a place to explore the students' ideas. Sometimes, the students are still confused to create narrative and recount texts although the teacher gave them clear explanations. In this part, the students can learn to identify the differences between recount and narrative texts. Three nests using interesting topics are provided. Here is an example of the nest activity:

a) Students choose a nest.

It provides three nests (red, yellow or blue nest) that can be identified by the students. In every nest, the students will find two different texts types (recount and narrative texts) that can be read several times.

b) Then, guess the topic of the texts.

The two given texts have the same topic such as dreaming. It can encourage students to read those texts and trigger the students to write a similar topic in different texts.

c) After reading the given text, students identify those two texts to know which one is a recount text by completing some tasks.

d) Next, learn how to write a recount text (generic structure and language focus).

e) Finally, the students do the tasks through a creativity activity. 


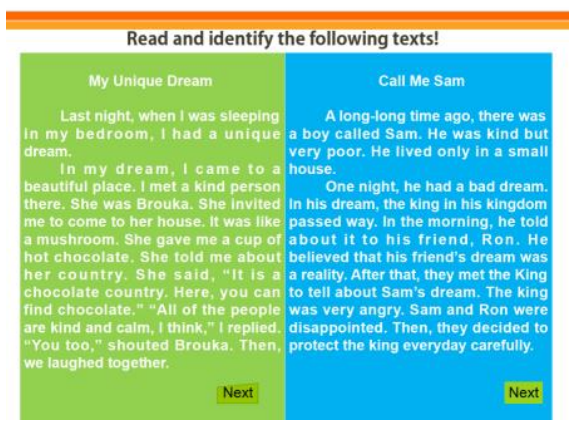

Figure 3. Nest: Task and Activity

(c) Key is a creative design to trigger students to write recount texts in accordance with the template provided. The "Save and edit" instruction is offered to help the students to write, edit and save their writing safely. The students can involve in this section if they got a password from the previous section. Here is an example of key activities:

a. Write a recount text based on the given clue on the left box.

b. Put your ideas into the provided template.

c. Use "save and edit" instruction if you need.

d. Then, submit it to your teacher by email.

e. The teacher can give his/her feedback to your writing.

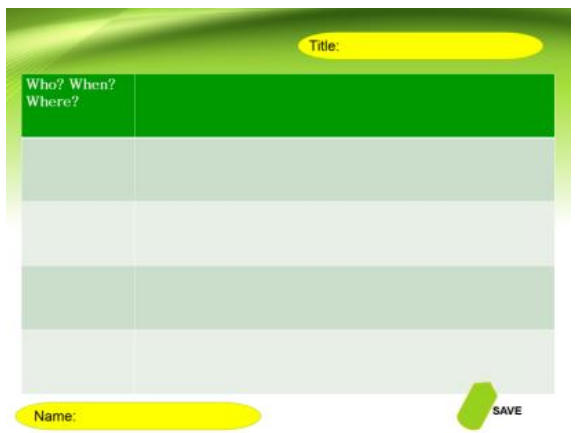

Figure 4. Key: Task and Activity

Finally, the forum Group Discussion (FGD) is held in an internal evaluation stage by attending two expert judgments and two teachers to fill out the instruments about the prototype of E-INK products related to the content, writing skills that develop tasks and activities in INK ways (Idyll, Nest and Key) and graphics. Based on the analysis of the data, the media were improved. There were some revisions, such as revisions in graphics. First, in the nest section, for example, the font of the texts given is too small. Then, the researcher revised it to make the texts readable for the students. Second, in the Idyll section, for example, this step only used songs with lyrics. It should use pictures to encourage the students' creativity when they listen to and read the lyrics of the song. Then, the researcher revised and added some pictures that associate with the songs. 

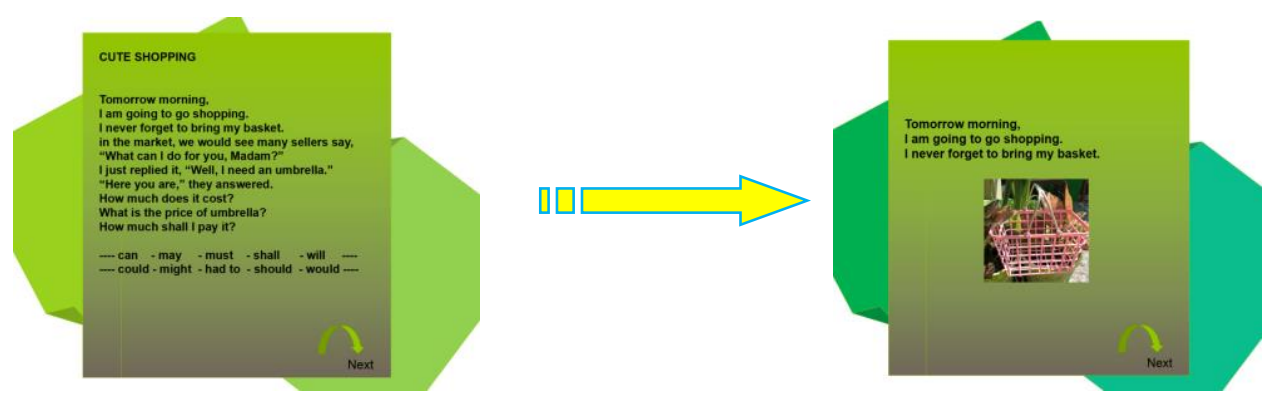

Figure 5. The Example of Song's Lyrics Using a Picture Template

By doing this research, the researcher found that tasks and activities in this product were suitable for basic competence and the students' need, several songs help to develop the students' ideas in creating recount texts and students enjoy writing recount texts using the provided writing template with save and edit models.

\section{CONCLUSION}

It can be concluded that the students got difficulties in writing recount texts, they often got confused to differentiate between recount and narrative texts so they wanted their teacher to pick out the materials, tasks and activities that could improve their knowledge in writing by using an inventive media, for teaching writing related to students' need. Therefore, the researcher decided to develop tasks and activities to teach writing recount texts by searching for ideas in the inventive songs, identifying the engrossing stories and writing using the provided template to improve students' creativity to write recount texts.

The prototype of E-INK media for teaching writing recount texts to the eighth graders students of junior high school serves their functions in developing students' writing skills in three steps namely Idyll, Nest and Key. It had been validated through the Forum Group Discussion (FGD) and the results are stated follows: a) All of the E-INKs' tasks and activities were suitable for basic competence and the students' need. b) E-INK afforded songs to develop the students' ideas in creating recount texts. c) Writing template offered save and edit models related to the students' interest. This research represents an innovative pedagogy in a changing world.

\section{REFERENCES}

Derewianka, B.1990. Exploring How Text Works. Sydney: Primary English Teaching Association.

Nunan, D.1996. The Self-Directed Teacher Managing the Learning Process. Cambridge Language Education.

Plomp, T.1997. Educational and Training System Design. Netherlands: University of Twente Faculty of Educational Science and Technology.

Richards, J. C. 2006. Communicative Language Teaching Today. Cambridge University Press.

Tomlinson, B., Hitomi, M. 2018. The Complete Guide to the Theory and Practice of

ACQUAINTING INVENTIVE MEDIA: E-INK TO TRIGGER STUDENTS' CREATIVITY IN WRITING RECOUNT TEXTS - LUKY TIASARI - DBB V13 N2 
Materials Development for Language Learning. Oxford: Wiley Blackwell. https://us.corwin.com/sites/default/files/upm-binaries/6635_tileston_9_ch_1.pdf.

ACQUAINTING INVENTIVE MEDIA: E-INK TO TRIGGER STUDENTS' CREATIVITY IN WRITING RECOUNT TEXTS - LUKY TIASARI - DBB V13 N2 